\title{
Performance of Multivariate Time Series on Forecasting the Tropospheric Ozone $\left(\mathrm{O}_{3}\right)$
}

\author{
Ahmad Fauzi Raffeeㄹ, Hazrul Abdul Hamid ${ }^{2 *}$, Siti Nazahiyah Rahmat ${ }^{1}$, \\ Muhammad Ismail Jaffar ${ }^{1}$ \\ ${ }^{1}$ Cluster of Water and Environmental Engineering, Faculty of Civil Engineering and Built Environment, \\ Universiti Tun Hussein Onn Malaysia, 86400 Batu Pahat, Johor \\ ${ }^{2}$ Mathematics Division, School of Distance Education, Universiti Sains Malaysia, 11800 Penang
}

Received: 14 January 2021

Accepted: 25 March 2021

\begin{abstract}
The tropospheric ozone $\left(\mathrm{O}_{3}\right)$ is known as a hazardous ambient air pollutant that adversely affects human health. Recently, many studies have been devoted to assess and monitor the $\mathrm{O}_{3}$ concentration due to its impact on society health. This study was carried out to develop a model to forecast $\mathrm{O}_{3}$ concentration. A comparison between univariate and multivariate time series to examine the most appropriate model was made. The air quality data used in this research was collected from three (3) stations namely Perai, Penang (industrial), Alor Setar, Kedah (urban) and Jerantut, Pahang (background). The selection of background station allows for comparisons to be made with stations closer to anthropogenic emissions. Based on Akaike Information Criterion (AIC), the appropriate multivariate time series to develop a forecasting model for Perai, Alor Setar and Jerantut monitoring stations were vector autoregressive - VAR(3), vector autoregressive - VAR(2) and vector moving average - VMA(2), respectively. The lowest root mean square error (RMSE) is 0.0053 which is for the multivariate time series model in Perai while for normalized absolute error (NAE) and mean absolute error (MAE), the lowest is in Jerantut with 0.0850 and 0.0013 respectively. Validation of the models using three error measures shows that the multivariate time series model performed better compared to the univariate time series model.
\end{abstract}

Keywords: time series, tropospheric ozone, air pollution

\section{Introduction}

The adverse effect of outdoor air pollutant on human health and well-being are consistently reported by many forms of research over the world [1-2]. Particulate

*e-mail: hazrul@usm.my matter (PM), nitrogen dioxide $\left(\mathrm{NO}_{2}\right)$, sulphur dioxide $\left(\mathrm{SO}_{2}\right)$, carbon monoxide $(\mathrm{CO})$ and tropospheric ozone $\left(\mathrm{O}_{3}\right)$ are among dominant outdoor air pollutants. Of all pollutants, the $\mathrm{O}_{3}$ is classified as a secondary pollutant. The $\mathrm{O}_{3}$ is noxious gaseous form by a series of complex reactions, non-linear, feedback-regulated processes between its precursors, such as nitrogen oxides $\left(\mathrm{NO}_{\mathrm{X}}\right)$, the volatile organic compound (VOC) at the presence of sunlight [3]. The $\mathrm{O}_{3}$ pollutant usually recorded higher 
concentrations in the afternoon due to the intensity of ultraviolet (UV) radiation that comes from the sun. The anthropogenic activities are the most common sources of $\mathrm{NO}_{\mathrm{x}}$ and VOC. Industrial activities, fossil fuel combustion and biomass are the major sources of $\mathrm{NO}_{2}$ [4-5]. While, VOC produced from vegetation, motor vehicles exhaust, agricultural and forest fires [6]. The adverse effects of $\mathrm{O}_{3}$ are well established in recent years [7-8].

The negative effects of $\mathrm{O}_{3}$ are associated with an effect on human health, climate change, crop yield and ecosystem. The lower atmosphere condition initiated $\mathrm{O}_{3}$ played critical role in tropospheric chemistry, whereas it being principal precursors to hydroxyl radical $(\mathrm{OH})$ which controlling oxidizing power [5]. More importantly, $\mathrm{O}_{3}$ is the main factor of photochemical smog and Global warming [9]. The formation, variation and behavior of $\mathrm{O}_{3}$ concentration strongly influence by several factors such as wind speed, relative humidity, ambient temperature and solar radiation [10]. These factors also played a significant role in dilution and dispersion of $\mathrm{O}_{3}$ concentration in ambient air. The numerous studies examined the high temperature, low wind speed, minimal rainfall and intensity of solar radiation could increase the $\mathrm{O}_{3}$ concentrations [11]. In the same way, $\mathrm{O}_{3}$ can be slightly reduced when degreasing heat of solar radiation, decreased water vapor has reduced the sources of radicals, increasing on cloud cover which is expected to result in a sensitive VOC chemistry [12].

At present, Malaysia initiates to be an industrial country with rapid industrialization, urbanization and economic growth. Due to accommodate human and industrial needs, the precursor of $\mathrm{NO}_{2}$ released by the power plant for energy supply, processing factory activities and motor vehicle producing $\mathrm{O}_{3}$ in the country. Currently, the major contributors of $\mathrm{NO}_{2}$ pollutants are power plants and motor vehicle. These contributors showed slightly increased and degraded each year for power plant and motor vehicle, respectively. Power plants contributed $61 \%$ in 2010 and increased to $66 \%$ in 2016. However, the $\mathrm{NO}_{2}$ contribution emission by motor vehicle decreased from $29 \%$ (2010) to $26 \%$ (2016) as shown in Fig. 1. The overall trend of $\mathrm{O}_{3}$ in Malaysia reported by the Department of Environment (DoE) had exceeded the Malaysian Ambient Air Quality Guidelines for $\mathrm{O}_{3}$ at $0.10 \mathrm{ppm}$ in urban areas [13]. This was due to the traffic density and conductive atmosphere which results in the $\mathrm{O}_{3}$ formation [14].

Nowadays, controlling the source of air pollutants is one of the major challenges in the world. The predicting models for air pollutant concentrations become imperative tools and produce an efficient management and control system in air quality. If any lack of conformity is examined, the related authority can use the data to advise or caution people about the effects [21]. The predicting models for forecasting air pollutants are divided into mathematical and physical models. In the last decade, several researchers widely applied the univariate time series models of an autoregressive moving average (AR) [22], moving average (ARMA) [23] and vector autoregressive moving average (ARIMA) [24] in predicting the future concentration of air pollutants dispersion. However, the application of the multivariate time series method is still very limited.

Besides, the research on air quality forecasting on time series especially relating on $\mathrm{O}_{3}$ concentration have been conducted previously but focused solely on univariate such as the study by Jamil et al. [25] where applied the univariate time series method of the autoregressive integrated moving average (ARIMA). Additionally, there has been a limited study on multivariate time series such as done in Taiwan and Spain [26-27]. However, all this study was solely on $\mathrm{PM}_{10}$ rather than $\mathrm{O}_{3}$ concentration. Thus, this study was carried out as a comparative study to prove that the

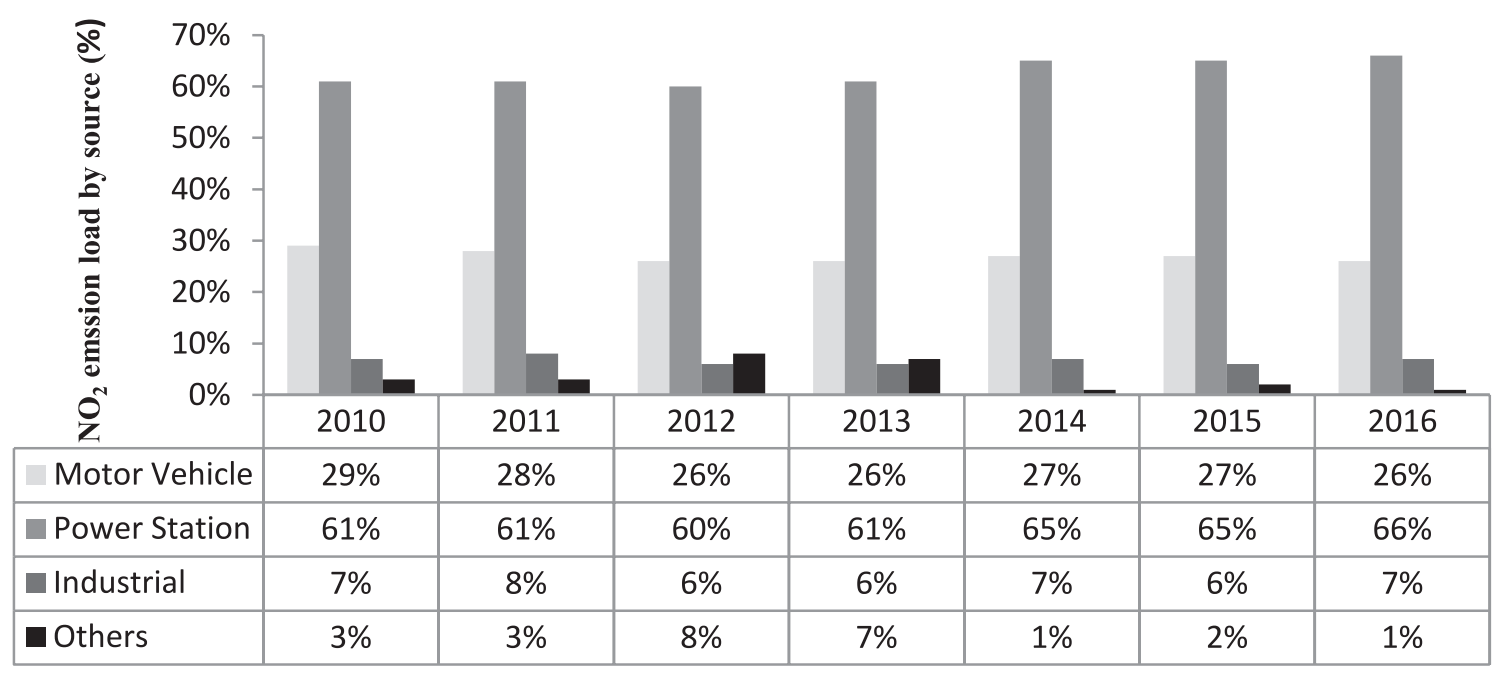

Fig. 1. Nitrogen dioxide $\left(\mathrm{NO}_{2}\right)$ load emission sources (\%) from 2010-2016 (Sources: [14-20]). 
multivariate time series outperformed the univariate time series for forecasting $\mathrm{O}_{3}$ concentration purposed. The main contribution of this study is to improve the accuracy of predictions as well as to understand the causal relationship between $\mathrm{O}_{3}$ and other pollutants or meteorological parameters. More accurate forecasting is needed to enable relevant parties to plan strategies in air quality control and also as an early warning for people who may be affected if the air quality level is poor.

This paper is organized as follows. Section 2 describes in detail the location of monitoring stations, air pollutants data including meteorological data and methods of study. Section 3 presents the application of univariate and multivariate time series methods. This section also describes the development of univariate and multivariate time series methods. Finally, Section 4 summarizes the main conclusions drawn.

\section{Materials, Data and Methods}

\section{Site Description}

Air quality in the country is monitored continuously and manually to detect any changes in the ambient air quality status that may cause harm to human health and the environment. Perai in Penang, Alor Setar in Kedah and Jerantut in Pahang which have been established as industrial, urban and background air monitoring stations, respectively, by the Department of the Environment (DoE), Malaysia were selected in this study. The area surrounding Perai station was developed from a mangrove swamp into the industrial area in northern Peninsular Malaysia. Alor Setar is the state capital of Kedah and the monitoring station is surrounded by large residential areas and business centres. While Jerantut station is surrounded by agricultural areas and traditional Malaysian villages with few local small industries. People who live in urban industrial and urban areas are most affected by air pollution especially children [28]. The $\mathrm{O}_{3}$ pollutant gave serious attention in the industrial and highly-populated continental region due to the potential human health impact [29]. Thus, people living in these areas may have the possibility be exposed more to air pollutants by anthropogenic sources. The details and description of the stations are illustrated in Table 1 and Fig. 2.

\section{Data}

The Department of Environment, Malaysia (DOE) is the responsible agency that monitors the country's air quality. As a part of Malaysian Continuous Air Quality Monitoring (CAQM) program, the $\mathrm{O}_{3}$ concentration was recorded using Teledyne $\mathrm{O}_{3}$ Analyser Model 400A UV Absorption. There were two sets of $\mathrm{O}_{3}$ concentration data utilised in this study. Firstly, the hourly average data set from January 2006 to December 2017 were used for descriptive statistics to examine the behavior pattern of $\mathrm{O}_{3}$ concentration. Secondly, the hourly data

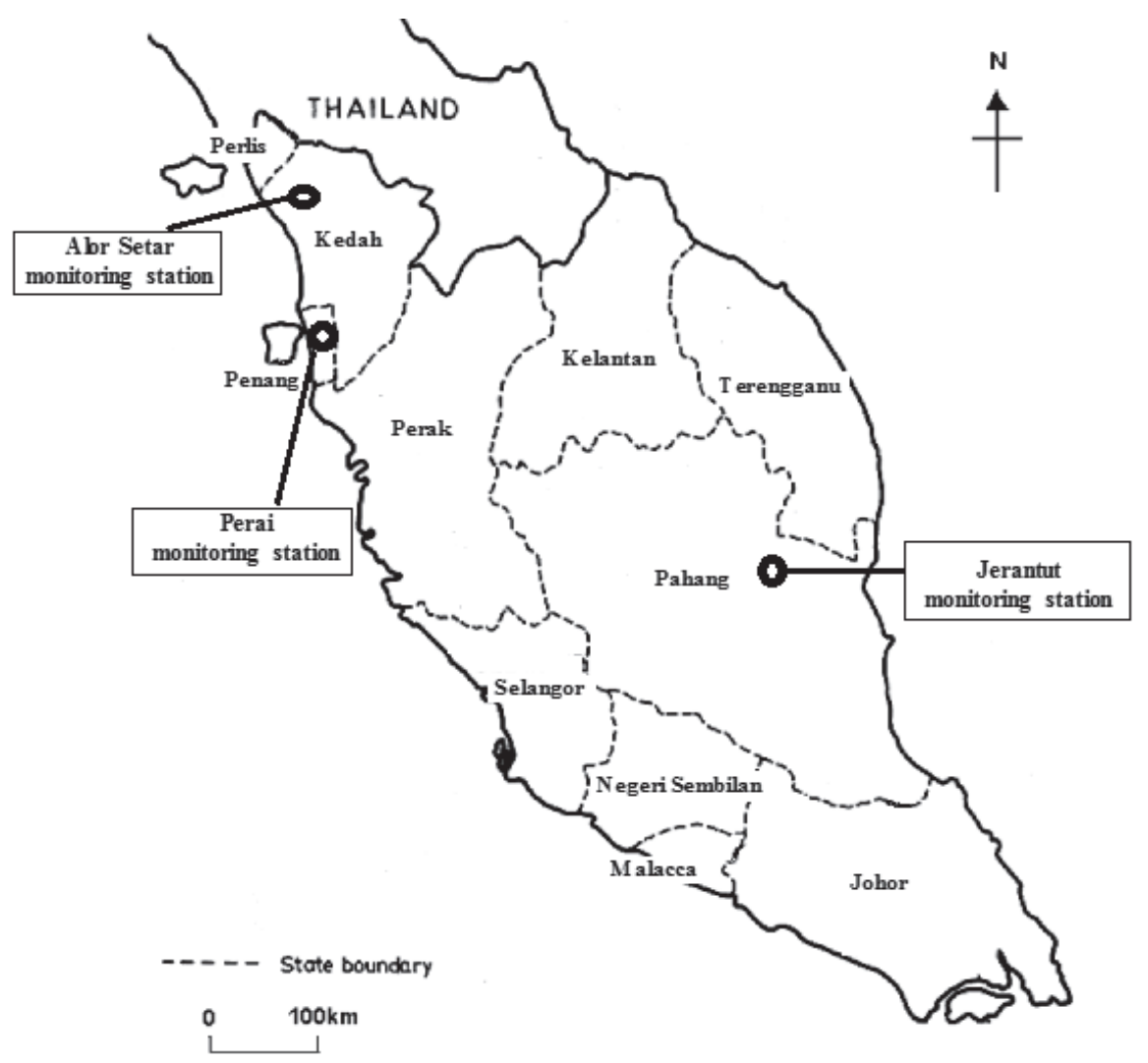

Fig. 2. Location of the selected monitoring stations. 
Table 1. Descriptions of monitoring stations.

\begin{tabular}{|c|c|c|}
\hline Monitoring station & Coordinates & Category \\
\hline Sek. Keb. Cederawasih, Taman Inderawasih, Perai & N05 $23.890^{\prime}$ 'E100 $24.194^{\prime}$ & Industrial \\
\hline Sek. Men. Agama Mergong, Alor Setar & N06 $08.218^{\prime}$ 'E100 $20.880^{\prime}$ & Urban \\
\hline Pejabat Kaji Cuaca, Batu Embun, Jerantut & N03 $58.238^{\prime}$ 'E102 $20.863^{\prime}$ & Background \\
\hline
\end{tabular}

was transformed to monthly average data to develop a statistical model for forecasting $\mathrm{O}_{3}$ using the time series method. A total of 144 monthly data were used with 138 data utilised for forecasting and the remaining for validation purposes. In the multivariate time series method, the other data set that examined to develop the model is particulate matter $\left(\mathrm{PM}_{10}\right)$, gaseous pollutants (i.e. sulphur dioxide $\left(\mathrm{SO}_{2}\right)$, nitrogen dioxide $\left(\mathrm{NO}_{2}\right)$ and carbon monoxide $(\mathrm{CO})$ ) and meteorological parameters (i.e. relative humidity, temperature and wind speed) also obtained from the DOE. The reliability and quality of all recorded data are guaranteed since it has undergone the quality control established by the standard provided by the DOE.

\section{Method}

The procedures of the time series are quite similar. The differences between univariate and multivariate time series procedures are at the estimation part and Granger causality test. The estimation for univariate considered only the $\mathrm{O}_{3}$ concentration as a single variable, while the multivariate time series consists of multiple single series referred to as component and involving stochastic models to describe and analyze the relationships among data sets. There are three phases in time series modelling which are identification, estimation and testing [30].

The Augmented Dicky-Fuller (ADF) test was used to determine the stationarity of the data series taken into consideration in this study. The ADF expression as in Equation (1) with the hypothesis is $\mathrm{H}_{0}$ : the time series data is non-stationary and $\mathrm{H}_{1}$ : time series data is stationary. If the critical value less than ADF value, the null hypothesis will be rejected [31].

$$
\mathrm{ADF}=\alpha_{0}+p_{1} y_{t-1}+\sum_{j=2}^{p-1} \beta_{j} \nabla y_{t-j}+e_{t}
$$

...where:

$\alpha_{0}$ - Drift Component

$e_{t}$ - independent and a homogeneous error term

Both time series models of univariate and multivariate have been identified for each type of model namely autoregressive (AR), moving average (MA) and autoregressive moving average (ARMA) for univariate models and vector autoregressive (VAR), vector moving average (VMA) and vector autoregressive moving average (VARMA) for multivariate models. The Akaike Information Criterion (AIC) as for lag length selection was used to identify the appropriate model part by part. The most suitable model was the model that consisted of the smallest AIC value [32]. Then, the most appropriate model which represented the univariate and multivariate models for each monitoring station was provided for comparison purposes. The AIC equation as in Equation (2) [31]

$$
A I C=2 k-2 \ln (L)
$$

...where:

$k$ - number of estimated parameters in the model.

$L$ - Maximum values of the likelihood function for the model.

The purpose of the estimation procedure was to create the forecasting values of $\mathrm{O}_{3}$ concentration. Each model involved in this process and produced its equation. The first model of univariate was AR and the expression is shown in Equation (3) where the process of order $p$ is denoted by $\operatorname{AR}(p)$ [33].

$$
y_{t}=\sum_{r=1}^{p} \phi_{r} y_{t-1}+\epsilon_{t}
$$

...where $\phi_{1}, \ldots, \phi_{r}$ defined as constant and $\in_{t}$ as a sequence of independent or uncorrelated random variables with mean 0 and variances $\sigma^{2}$.

The second model of univariate was MA process of order $q$ which denoted as $\operatorname{MA}(q)$ and the expression of the model is shown in Equation (4) [33]:

$$
y_{t}=\sum_{s=0}^{q} \theta s+\epsilon_{t-s}
$$

...where $\theta_{1}, \ldots, \theta_{q}$ defined as constant, $\theta_{0}=1$ and $\epsilon_{t}$ a sequence of independent (or uncorrelated random variables with mean 0 and variances $\sigma^{2}$.

The third univariate model was the combination of $\operatorname{AR}(p)$ and $\operatorname{MA}(q)$ model which known as autoregressive moving average (ARMA) were denoted as $\operatorname{ARMA}(p, q)$ and the equation is shown in Equation (5) [33]:

$$
y_{t}=\sum_{r=1}^{p} \phi_{r} y_{t-1}=\sum_{s=0}^{q} \theta s+\epsilon_{t-s}
$$


...where the $\epsilon_{t}$ is white noise. The appropriate $\theta, \phi$ is the process of stationary of the data series.

Besides the three univariate models explained above, another three multivariate time series models were also applied to compare the results. The first model of multivariate namely as VAR. The VAR model describes the situation in which the present value of a series depends on its previous values. This model is an extension of the univariate autoregressive model (AR). The VAR model of order $p$, abbreviated VAR(p) given as in Equation (6) [34]:

$$
\left(I-\Phi_{1} B-\cdots-\Phi_{p} B^{p}\right) y_{t}=a_{t}
$$

...where $z_{t}$ is an $(m \times 1)$ vector observed variables, $z_{t}$ denoted multivariate white noise and $\Phi$ is a matrix polynomial of order $p$ in the backward shift operator $B$.

The VMA was the second model of the multivariate time series applied in the study. The model was an extension from the MA for univariate forecasting. The phenomena in which events produce an immediate effect that only lasts for short periods is referred to in this model. The abbreviated $\operatorname{VMA}(q)$ is shown in Equation (7) [34]:

$$
y_{t}=\left(I-\Theta_{1} B-\cdots-\Theta_{p} B^{p}\right) a_{t}
$$

...where $z_{t}$ is an $(m \times 1)$ vector observed variables, $z_{t}$ denoted multivariate white noise and $\Theta$ is a matrix polynomial of order $q$ in the backward shift operator $B$. The third model was defined as VARMA. Similar to univariate, this model was the combination of VAR and VMA models. In general, the $\operatorname{VARMA}(p, q)$ process given by Equation (8) [34]:

$$
\Phi_{p}(B) y_{t}=\Theta_{q}(B) a_{t}
$$

the autoregressive and moving average matrix polynomial of orders $p$ and $q$ respectively, where $\Phi_{p}$ and $\Phi_{q}$ is nonsingular $m \times m$ matrices. The process is stationary if the zeros of the determinantal polynomial $\left|\Phi_{p}(B)\right|$ are outside the unit circle.

Besides, for the multivariate model, the Granger causality test was used to determine the influence of other variables of pollutants or meteorological parameters and the equation is shown in Equations (9) and (10) [35]:

$$
y_{t}=g_{0}+a_{1} y_{t-1}+\ldots+a_{p} y_{t-1}+b_{1} x_{t-1}+\ldots+b_{p} x_{t-p}+u_{t}
$$

$$
x_{t}=H_{o}+c_{1} x_{t-1}+\ldots+c_{p} x_{t-p}+d_{1} y_{t-1}+\ldots+d_{p} y_{t-p}+v_{t}
$$

Then, testing $H_{0}: b_{1}=b_{2}=\ldots \ldots=b_{p}=0$, against $H_{A}: x$ Granger causes $y$. Similarly, testing $H_{0}: d_{1}=d_{2}$ $=\ldots \ldots=d_{p}=0$, against $H_{A}: y_{t}$ Granger causes $x_{t}$. The $H_{0}: \quad b_{1}$ represents the dependent series while the $H_{\mathrm{o}}: d_{1}$ represents the independent series. While $a$ is the coefficient values of the series. In each case, a rejection of the null implies there is Granger causality. Note that $x_{t}$ and $y_{t}$ series are in 'level' form which simply means that the data is not in the 'difference' form where $u_{t}$ and $v_{t}$ are white noise error terms.

The final stage in this works was the testing part. To measure the discrepancies between the forecast and actual values, performance indicator (also known as a goodness of fit criteria) regression models namely root mean absolute error (RMSE), normalized absolute error (NAE) and mean absolute error (MAE) were used. RMSE summarizes the difference between the observed and imputed concentrations and is used to provide the average error [36]. NAE is more sensitive in measuring residual error [37] and MAE is the absolute difference between prediction and actual observation on average over the test sample where all individual differences have equal weight [38]. The equation for RMSE, NAE and MAE are shown in Equations (11), (12) and (13) respectively.

$$
\begin{gathered}
R M S E=\sqrt{\frac{1}{N} \sum_{i=1}^{N}\left(P_{i}-\mathrm{O}_{i}\right)^{2}} \\
N A E=\frac{\sum_{i=1}^{N}\left|P_{i}-O_{i}\right|}{O_{i}} \\
M A E=\frac{1}{N} \sum_{i=1}^{N}\left|P_{i}-O_{i}\right|
\end{gathered}
$$

...where, $P$ is forecast values, $O$ is observed values. While, $N$ referred to the number of samples. If the values of performance error near zero, it means the forecast models are a better approach compared to another.

\section{Results and Discussion}

The pattern and behavior of $\mathrm{O}_{3}$ concentrations were analyzed using descriptive statistics. The results of the descriptive statistics are presented in Table 2. The unit of measurement is part per million ( $\mathrm{ppm}$ ). The maximum of $\mathrm{O}_{3}$ concentration exceeded the Malaysia Ambient Air Quality Guideline (MAAQS) at $0.1 \mathrm{ppm}$ for Perai and Alor Setar monitoring stations. The highest concentration recorded was 0.1763 ppm at Perai station followed by $0.1032 \mathrm{ppm}$ at Alor Setar station. The Perai station recorded the highest mean with $0.0190 \mathrm{ppm}$ and Jerantut recorded the lowest mean value with $0.0152 \mathrm{ppm}$. As expected due to high values of mean, the standard deviation also showed high value in industrial monitoring station (Perai) compared to others. 
Table 2. Descriptive statistics for $\mathrm{O}_{3}$ concentration by monitoring stations.

\begin{tabular}{|c|c|c|c|}
\hline Station & Perai & Alor Setar & Jerantut \\
\hline Mean & 0.0190 & 0.0180 & 0.0152 \\
\hline Median & 0.0136 & 0.0152 & 0.0130 \\
\hline Std. Deviation & 0.0177 & 0.0117 & 0.0104 \\
\hline Maximum & 0.1763 & 0.1032 & 0.0546 \\
\hline
\end{tabular}

The multivariate times series is distinguished by allowing more than one variable for developing a time series model. This study used only $\mathrm{O}_{3}$ concentration for developing a univariate time series model. Meanwhile, the multivariate model was analyzed using the $\mathrm{O}_{3}$ concentration as the dependent variable and particulate matter $\left(\mathrm{PM}_{10}\right)$, gaseous pollutants $\left(\mathrm{SO}_{2}, \mathrm{NO}_{2}, \mathrm{CO}\right)$ and meteorological variables (relative humidity, wind speed and temperature) categorized as independent variables. The developed multivariate model, considered the significant variable while the insignificant variable was removed.

The stationarity test was conducted on all variables and the results are summarised in Table 3. This result showed that Perai monitoring station had six stationary variables (i.e. $\mathrm{O}_{3}, \mathrm{PM}_{10}, \mathrm{SO}_{2}, \mathrm{CO}$, wind speed, temperature and relative humidity) with significant values less than 0.05 . In contrast, Nilai and Jerantut monitoring stations had two and three insignificant variables with significant values of more than 0.05 (i.e. $\mathrm{PM}_{10}$ and relative humidity for Nilai monitoring station, while $\mathrm{NO}_{2}$, temperature and relative humidity for Jerantut monitoring station).

The multivariate times series is distinguished by allowing more than one variable for developing a time series model. This study used only $\mathrm{O}_{3}$ concentration for developing a univariate time series model. Meanwhile the multivariate model was analyzed using the $\mathrm{O}_{3}$ concentration as dependent variable and particulate matter $\left(\mathrm{PM}_{10}\right)$, gaseous pollutants $\left(\mathrm{SO}_{2}, \mathrm{NO}_{2}, \mathrm{CO}\right)$ and meteorological variables (relative humidity, wind speed and temperature) categorized as independent variables. The developed multivariate model, considered the significant variable while the insignificant variable was removed.

The stationarity test was conducted on all variables and the results are summarised in Table 3. This result showed that Perai monitoring station had six stationary variables (i.e. $\mathrm{O}_{3}, \mathrm{PM}_{10}, \mathrm{SO}_{2}, \mathrm{CO}$, wind speed, temperature and relative humidity) with significant values less than 0.05 . In contrast, Nilai and Jerantut monitoring stations had two and three insignificant variables with significant values of more than 0.05 (i.e. $\mathrm{PM}_{10}$ and relative humidity for Nilai monitoring station, while $\mathrm{NO}_{2}$, temperature and relative humidity for Jerantut monitoring station).

The results of this stationarity test observed that $\mathrm{O}_{3}$ concentration was stationary at all monitoring stations and the estimation process for univariate time series can proceed to determine the best model. The multivariate procedure was continued with Granger causality test to examine the significant variables that influenced the concentration of $\mathrm{O}_{3}$.

In order to examine the independent variables that possible to influence the $\mathrm{O}_{3}$ concentration, Granger causality was applied to all monitoring stations (Table 4). From the results obtained, it can be concluded that the gaseous pollutants of $\mathrm{SO}_{2}$ and $\mathrm{NO}_{2}$ were the influenced variables to $\mathrm{O}_{3}$ concentration at Perai and Jerantut monitoring stations, respectively. Meanwhile, the meteorological variables namely wind speed (WS) was found to be an influenced factor to $\mathrm{O}_{3}$ concentration at Alor Setar monitoring station. It also can be concluded that only one variable for each monitoring station was taken into consideration for developing a multivariate model. The $\mathrm{SO}_{2}$ and $\mathrm{NO}_{2}$ were expected as variables that influenced the $\mathrm{O}_{3}$ concentration. This finding was similar to a previous study by Wang et al. [39]. However, the result of Granger causality test for WS at Nilai monitoring station was unexpected. There were limited finding on the significant effect of WS to $\mathrm{O}_{3}$ concentration. The slow wind speed might be the factor influencing $\mathrm{O}_{3}$ concentration. Additionally, the slow wind speed allowed more solar radiation hence gave this relation.

Perai monitoring station is surrounded by industrial activities where Perai is known as the main industrial

Table 3. The ADF test statistics for all variables.

\begin{tabular}{|c|c|c|c|c|c|c|c|c|c|}
\hline Station & $\mathrm{ADF}$ value & $\mathrm{O}_{3}$ & $\mathrm{PM}_{10}$ & $\mathrm{SO}_{2}$ & $\mathrm{NO}_{2}$ & $\mathrm{CO}$ & $\begin{array}{c}\text { Wind } \\
\text { speed }\end{array}$ & Tempe-rature & $\begin{array}{c}\text { Relative } \\
\text { humidity }\end{array}$ \\
\hline \multirow{2}{*}{ Perai } & $\mathrm{ADF}$ & -1.3288 & -1.7461 & -0.9017 & -0.5131 & -0.4012 & -1.3411 & -0.945 & -0.007 \\
\cline { 2 - 11 } & $\mathrm{Sig}$ & $<0.0215$ & $<0.0255$ & $<0.0001$ & 0.7871 & 0.03364 & $<0.0014$ & $<0.0030$ & $<0.0001$ \\
\hline \multirow{2}{*}{ Alor Setar } & $\mathrm{ADF}$ & -1.4782 & -1.8567 & -2.5856 & -1.0113 & -1.628 & -1.7357 & -0.7734 & -0.543 \\
\cline { 2 - 11 } & $\mathrm{Sig}$ & $<0.0001$ & 0.1582 & 0.0013 & 0.0197 & $<0.0001$ & 0.0004 & $<0.0140$ & $<0.8272$ \\
\hline \multirow{2}{*}{ Jerantut } & $\mathrm{ADF}$ & -1.0548 & -1.5848 & -1.8744 & -0.7912 & -1.3534 & -0.7404 & -0.3998 & -0.5062 \\
\cline { 2 - 10 } & $\mathrm{Sig}$ & $<0.0417$ & 0.0239 & $<0.0001$ & 0.2596 & 0.0079 & 0.0228 & 0.2816 & 0.8492 \\
\hline
\end{tabular}

*Results in boldface indicate significant values more than 0.05 monitoring station 
Table 4. Granger causality results.

\begin{tabular}{|c|c|c|c|}
\hline Station & Parameter & t-statistics & Significant \\
\hline Perai & $\mathrm{NO}_{2}$ & 2.665 & 0.0087 \\
\hline Alor Setar & $\mathrm{WS}$ & 2.263 & 0.0254 \\
\hline Jerantut & $\mathrm{SO}_{2}$ & 2.515 & 0.0132 \\
\hline
\end{tabular}

Table 5. Lag selection criteria of univariate and multivariate.

\begin{tabular}{|c|c|c|c|}
\hline Method & Station & Model & AIC \\
\hline \multirow{4}{*}{ Univariate } & Perai & $\operatorname{AR}(1)$ & -7.7975 \\
\cline { 2 - 4 } & Alor Setar & $\operatorname{ARMA(1,1)~}$ & -6.5656 \\
\cline { 2 - 4 } & Jerantut & $\operatorname{MA}(2)$ & -8.7955 \\
\hline \multirow{3}{*}{ Multivariate } & Perai & $\operatorname{VAR}(3)$ & -23.6990 \\
\cline { 2 - 4 } & Alor Setar & $\operatorname{VAR}(2)$ & -8.3943 \\
\cline { 2 - 4 } & Jerantut & $\operatorname{VMA}(2)$ & -22.8724 \\
\hline
\end{tabular}

area in Penang. This might be the main cause of gaseous of $\mathrm{NO}_{2}$ influence the $\mathrm{O}_{3}$ concentration where it's releasing from industrial processing activities in this area. Meanwhile, at the Jerantut monitoring station, the gaseous of $\mathrm{SO}_{2}$ influencing the $\mathrm{O}_{3}$ concentration due to the release from small industrial facilities and combustion of fuel from mobile sources since this area is situated in a rural area. Unexpected relation found in Alor Setar monitoring station reveals that WS as the significant variable influence the $\mathrm{O}_{3}$ concentration in this area. The monitoring location is located approximately less than $20 \mathrm{~km}$ from the Straits of Malacca. This location might be caused by favorable wind speed in this area which influences the $\mathrm{O}_{3}$ concentration whereas the heat and the sea salt are transported to ground that caused of this relationship.

The procedure was then continued to the identification part. This procedure determines the most appropriate model to develop for both time series methods. The appropriate univariate and multivariate time series based on Akaike Information Criterion (AIC) as well the performance errors are presented in Table 5. The previous study has been suggested that the value of $p+q$ must be equal to or less than 3 [40]. The values of $p$ and $q$ represent the previous value that is used for forecasting purposes. The high lag
AIC numbers lead to obtaining the high forecast error value. Based on the results in Table 5, the univariate time series gave the $\operatorname{AR}(1), \operatorname{ARMA}(1,1)$ and $\mathrm{MA}(2)$ as the most appropriate models for Perai, Alor Setar and Jerantut monitoring stations, respectively. Meanwhile, for multivariate time series, a similar model of VAR but different lag numbers were found in Perai and Alor Setar, and VMA for Jerantut monitoring station. The multivariate appropriate models were VAR(3) for Perai and VAR(2) for Alor Setar, while VMA(2) for Jerantut monitoring stations.

The root mean square error (RMSE), normalized absolute error (NAE) and mean absolute error (MAE) were used for verification purposes and the results are also shown in Table 6. The validation used the data from July 2017 to December 2017 by using the monthly simulation data set from January 2006 to June 2017. The results of the performance error also showed that the method of multivariate time series was better compared to the univariate time series for all three monitoring stations. At Perai and Alor Setar stations, all three performance errors for multivariate time series gave good results. The values of RMSE, NAE and MAE were $0.0053,0.1003$ and 0.0022 , respectively, for Perai station, and 0.0076, 0.1758 and 0.0031 , respectively, for Alor Setar station. Although Jerantut station showed only two multivariate performance errors better than univariate, it was sufficient to conclude that the multivariate time series method was more appropriate to be applied.

These results also indicated that the multivariate time series were applied at all monitoring stations in this study with a model of VAR(3) for Perai, VAR(2) for Alor Setar and VMA(2) for Jerantut monitoring stations. For Alor Setar and Jerantut stations, lag number two represented the two months previous data while lag number three for Perai station represented the three months previous data were taken into consideration to obtain the forecast values. Additionally, even though they gave a similar model of VAR, it should be noted that the influence of variables based on the Granger causality test was different from each monitoring station. This was due to the location and surrounding areas of air monitoring stations.

Finally, the equation for the multivariate time series model was obtained for each monitoring station based on the appropriate model selection. The multivariate equations were developed to forecast $\mathrm{O}_{3}$ concentration one month ahead of. and given as follows:

Table 6. Performance error results for all monitoring stations.

\begin{tabular}{|c|c|c|c|c|c|c|}
\hline \multirow{2}{*}{ Station/Error } & \multicolumn{2}{|c|}{ RMSE } & \multicolumn{2}{c|}{ NAE } & \multicolumn{2}{c|}{ MAE } \\
\cline { 2 - 7 } & Univariate & Multivariate & Univariate & Multivariate & Univariate & Multivariate \\
\hline Perai & 0.0055 & 0.0053 & 0.1048 & 0.1003 & 0.0023 & 0.0022 \\
\hline Alor Setar & 0.0138 & 0.0076 & 0.3169 & 0.1758 & 0.0056 & 0.0031 \\
\hline Jerantut & 0.0049 & 0.0366 & 0.1271 & 0.0850 & 0.0020 & 0.0013 \\
\hline
\end{tabular}



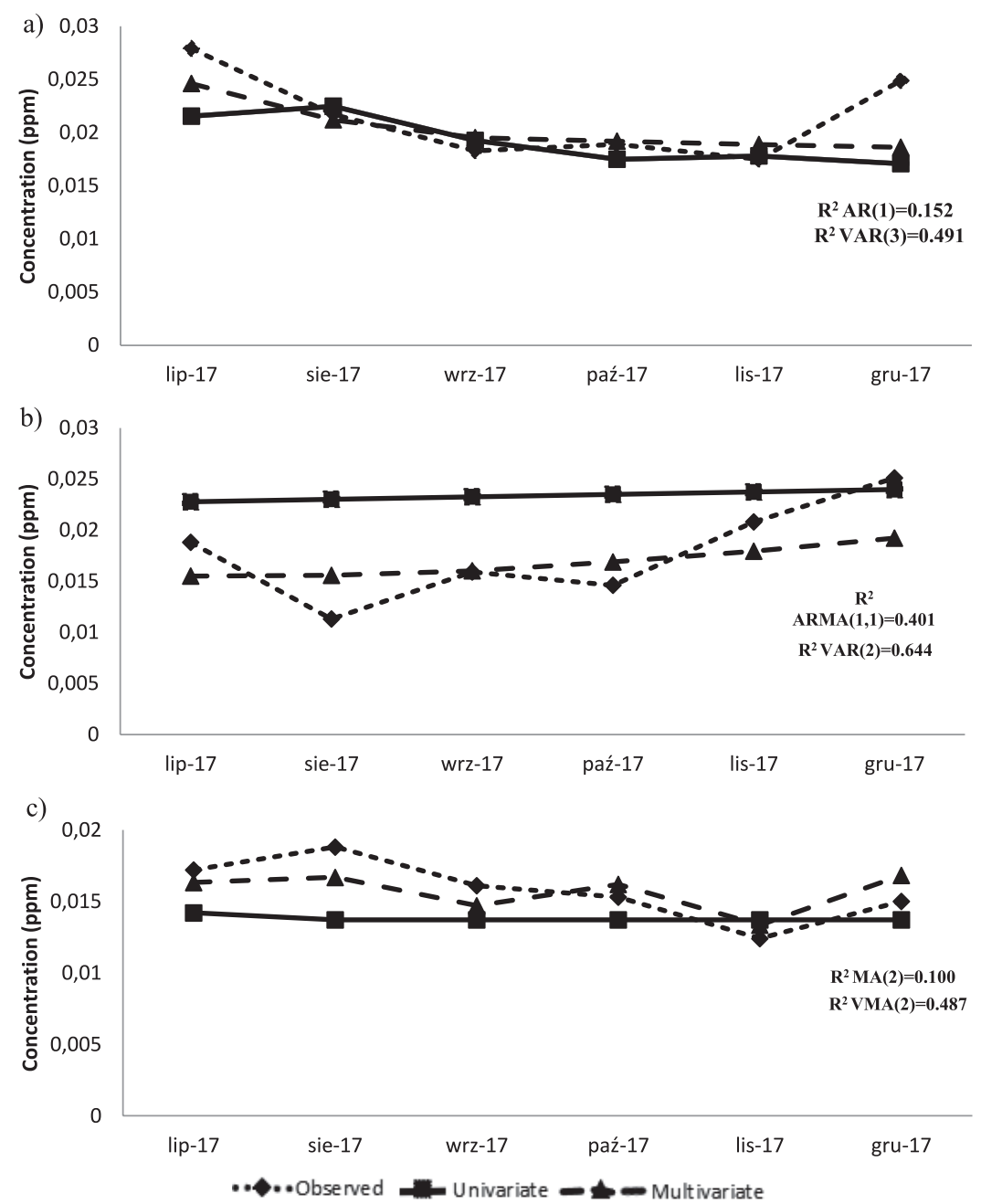

Fig. 3. The actual versus forecast value for a) Perai, b) Alor Setar and c) Jerantut monitoring stations.

For Perai monitoring station:

$$
\begin{aligned}
& \mathrm{O}_{3}=0.007628452+\left(0.4691 * \mathrm{O}_{3, \mathrm{t}-1}\right)+\left(0.798 * \mathrm{NO}_{2}{ }^{{ }_{\mathrm{t}-1}}\right) \\
& +\left(-0.065465^{*} \mathrm{O}_{3, \mathrm{t}-2}\right)+\left(-0.108 * \mathrm{NO}_{2 \mathrm{r}_{\mathrm{t}-2}}\right) \\
& +\left(0.0171 * \mathrm{O}_{3, \mathrm{t}-3}\right)+\left(-0.46^{*} \mathrm{NO}_{2}{ }_{\mathrm{t}-\mathrm{3}-3}\right)
\end{aligned}
$$

For Alor Setar monitoring station:

$$
\begin{array}{r}
\mathrm{O}_{3}=-0.00195626+\left(0.533^{*} \mathrm{O}_{3{ }^{\prime}-1}\right)+\left(0.00118^{*} \mathrm{WS}_{\mathrm{t}_{\mathrm{t}-1}}\right) \\
+\left(0.25^{*} \mathrm{O}_{3^{3} \mathrm{t}-2}\right)+\left(-0.000295^{*} \mathrm{WS}_{\mathrm{r}_{\mathrm{t}-2}}\right)
\end{array}
$$

For Jerantut monitoring station:

$$
\begin{array}{r}
\mathrm{O}_{3}=0.01470535-\left(-0.146 * \mathrm{O}_{3},{ }_{\mathrm{t}-1}\right)-\left(0.1 * \mathrm{SO}_{2},{ }_{\mathrm{t}-1}\right) \\
-\left(-0.0788 * \mathrm{O}_{3},{ }_{\mathrm{t}-2}\right)-\left(0.7 * \mathrm{SO}_{2},{ }_{\mathrm{t}-2}\right)
\end{array}
$$

The observed and predicted values for observation, best univariate and multivariate time series method are shown in Fig. 3. The prediction values for one month in advance can be obtained using the equation provided earlier. Based on the presented graph, the highest difference occurred in December 2017 for Perai and Alor Setar monitoring stations. The huge difference between observed and actual was due to the high recorded value of $\mathrm{O}_{3}$ concentration at both locations compared to the Jerantut monitoring station. Additionally, the results of the descriptive statistics above proved that the mean and standard deviation at these two stations were high compared to Jerantut station.

The developed multivariate time series models are possible and sufficient to apply for forecast the future concentration of $\mathrm{O}_{3}$. The forecasting model can be very useful to any related government agency, nongovernment organization or individual for an early measure to reduce the possible exceed limit of $\mathrm{O}_{3}$ concentration in the future as well as to plan outdoor activities.

\section{Conclusions}

This study selected three different types of air quality monitoring stations to examine the appropriate time series model that can be applied to forecast the $\mathrm{O}_{3}$ concentration. The Akaike Information Criterion (AIC) was used to examine the appropriate model for univariate is AR(1) with values of AIC is -7.7975, 
$\operatorname{ARMA}(1,1)$ with values of $\mathrm{AIC}$ is -6.5656 and $\mathrm{MA}(2)$ with the value of AIC is -8.7955. Meanwhile, for the multivariate method, the AIC found VAR(3) for Perai, $\operatorname{VAR}(2)$ for Alor Setar and VMA(2) for Jerantut as the appropriate models with values of $-23.6990,-8.3943$ and -22.8724 , respectively.

The results of validation using performance errors namely RMSE, MAE and NAE showed that the multivariate overcome the univariate time series. This indicated that all three monitoring stations, the multivariate time series model were better compared to the univariate model. Since the multivariate time series outperformed univariate time series, the different variables that influenced $\mathrm{O}_{3}$ concentration to forecast future $\mathrm{O}_{3}$ values were found at each monitoring station. At Perai station, the significant variable was $\mathrm{NO}_{2}$ while at Jerantut station the significant variable was $\mathrm{SO}_{2}$. Both variables were expected since these variables known as a precursor of $\mathrm{O}_{3}$ concentration. Contrary to Alor Setar, where the unexpected significant variables were observed, namely WS. Three equations were successfully developed to forecast $\mathrm{O}_{3}$ concentration at three monitoring stations. These equations can be used to forecast $\mathrm{O}_{3}$ concentration based on other parameters that contribute to the reading of $\mathrm{O}_{3}$ concentration. These models are also useful for better short-term forecasting and can be used by local authorities as a guide in predicting and planning the air quality control strategies.

\section{Acknowledgements}

This research was supported by Universiti Sains Malaysia Short Term Grant (PJJAUH/6315089) and Graduate Incentive Scheme (Vote U792) funded by the Research Management Centre (RMC), Universiti Tun Hussein Onn Malaysia. The authors would like to thank the Department of Environment (DOE), Malaysia, for generously providing the air quality data used in this study.

\section{Conflict of Interest}

The authors declare no conflict of interest.

\section{References}

1. ZHANG D., AUNAN K., MARTIN SEIP H., LARSSEN S, LIU J., Zhang D. The assessment of health damage caused by air pollution and its implication for policy making in Taiyuan, Shanxi, China. Energy Policy, 38 (1), 491, 2010.

2. D’AMATO G., BAENA-CAGNANI C.E., CECCHI L., ANNESI-MAESANO I., NUNES C., ANSOTEGUI I., D'AMATO M., LICCARDI G., SOFIA M., CANONICA W.G. Climate change, air pollution and extreme events leading to increasing prevalence of allergic respiratory diseases. Multidisciplinary Respiratory Medicine, 8 (1), 12, 2013.

3. RAFFEE A.F., ABDUL HAMID H., RAHMAT S.N., JAFFAR M.I. Vector autoregressive model: A multivariate time series to forecast the ground level ozone $\left(\mathrm{O}_{3}\right)$ concentration in Malaysia. Chiang Mai Journal of Science, 47 (6), 1297, 2020.

4. LATIF M.T., DOMINICK D., AHAMAD F., AHAMAD N.S., KHAN M.F., JUNENG L., XIANG C.J., NADZIR M.S.M., ROBINSON A.D., ISMAIL M., MEAD M.I., HARRIS N.R.P. Seasonal and Long Term Variations of Surface Ozone Concentrations in Malaysia Borneo. Science of Total Environment, 573, 494, 2016.

5. ZAINORDIN N.S., RAMLI N.A., ELBAYOUMI M. Distribution and Temporal Behaviour of $\mathrm{O}_{3}$ and $\mathrm{NO}_{2}$ Near Selected Schools in Seberang Perai, Pulau Pinang and Parit Buntar, Perak, Malaysia. Sains Malaysiana, 46 (2), 197, 2017.

6. EL-FADEL M., ZEIN M., NUWAYHID I., JAMALI D., SADEK S. Environmental management of ozone in Beirut urban areas. Environmental Management and Health, 13 (5), 47, 2002.

7. MADANIYAZI L., NAGASHIMA T., GUO Y., PAN X., TONG S. Projecting ozone-related mortality in East China. Environment International, 92-93, 165, 2016.

8. LEFOHN A.S., MALLEY C.S., SMITH L., WELLS B., HAZUCHA M., SIMON H., NAIK V., MILLS G., SCHULTZ M.G., PAOLETTI E., DE MARCO A., XU X., ZHANG L., WANG T., NEUFELD H.S., MUSSELMAN R.C., TARASICK D., BRAUER M., FENG Z., TANG H., KOBAYASHI K., SICARD P., SOLBERG S., GEROSA G. Tropospheric ozone assessment report: Global ozone metrics for climate change, human health, and crop/ecosystem research. Elementa: Science of the Anthropocene, 6 (1), 2, 2018.

9. WANG T., XUE L., BRIMBLECOMBE P., FAT Y., LI L., ZHANG L. Ozone pollution in China: A review of concentrations, meteorological influences, chemical precursors, and effects. Science of Total Environment, 575, $1582,2017$.

10. ZHANG H., WANG Y., HU J., YING Q., HU X. Relationships between meteorological parameters and criteria air pollutants in three megacities in China. Environmental Research, 140, 242, 2015.

11. TOH Y.Y., LIM S.F., VON GLASOW R. The influence of meteorological factors and biomass burning on surface ozone concentrations at Tanah Rata, Malaysia. Atmospheric Environment, 70, 435, 2013.

12. LATIF M.T., HUEY L.S., JUNENG L. Variations of surface ozone concentration across the Klang Valley, Malaysia. Atmospheric Environment, 61, 434, 2012.

13. DEPARTMENT OF ENVIRONMENT, M. Malaysia Environmental Quality Report 2016, Kuala Lumpur, 2016.

14. DEPARTMENT OF ENVIRONMENT, M. Malaysia Environmental Quality Report 2015, Kuala Lumpur, 2015.

15. DEPARTMENT OF ENVIRONMENT, M. Malaysia Environmental Quality Report 2010, Kuala Lumpur, 2010.

16. DEPARTMENT OF ENVIRONMENT, M. Malaysia Environmental Quality Report 2011, Kuala Lumpur, 2011.

17. DEPARTMENT OF ENVIRONMENT, M. Malaysia Environmental Quality Report 2012, Kuala Lumpur, 2012.

18. DEPARTMENT OF ENVIRONMENT, M. Malaysia Environmental Quality Report 2013, Kuala Lumpur, 2013.

19. DEPARTMENT OF ENVIRONMENT, M. Malaysia Environmental Quality Report 2014, Kuala Lumpur, 2014. 
20. DEPARTMENT OF ENVIRONMENT, M. "Annual Report 2016" Kuala Limpur, 2016.

21. AZID A., JUAHIR H., TORIMAN M.E., ENDUT A., KAMARUDIN M.K.A., RAHMAN M.N.A., HASNAM C.N.C., SAUDI A.S.M., Yunus K. Source apportionment of air pollution: A case study in Malaysia. Jurnal Teknologi 72 (1), 83, 2015.

22. SANSUDDIN N., RAMLI N.A., YAHAYA A.S., YUSOF N.F.F.M., GHAZALI N.A., AL-MADHOUN W.A. Statistical analysis of $\mathrm{PM}_{10}$ concentrations at different locations in Malaysia. Environmental Monitoring and Assessment, 180 (1-4), 573, 2011.

23. ABDUL HAMID H., UL-SAUFIE A.Z., AHMAT H. Characteristic and Prediction of Carbon Monoxide Concentration using Time Series Analysis in Selected Urban Area in Malaysia. MATEC Web Conference, 103, 2017.

24. ISMAIL M., IBRAHIM M.Z., IBRAHIM T.A. Time Series Analysis of Surface Ozone Monitoring Records in Kemaman, Malaysia. Sains Malaysiana, 40 (5), 411, 2011.

25. JAMIL N.I., ROZITA W., MAHIYUDDIN W., IZZAH A.N., LATIF M.T. Forecasting Ozone Concentrations Using Box-Jenkins ARIMA Modeling in Malaysia. American Journal of Environmental Science 14 (3), 118, 2018.

26. JUNG HSU K. Time Series Analysis of the Interdependence Among Air Pollutants. Atmospheric Environment, 26 (4), 91, 1992.

27. NIETO P.J.G., LASHERAS F.S., GARCÍA-GONZOLA E., JUEZ F.J.D.C. $\mathrm{PM}_{10}$ concentration forecasting in the metropolitan area of Oviedo (Northern Spain) using models based on SVM, MLP, VARMA and ARIMA: A case study. Science of Total Environment, 621, 753, 2018.

28. OH I., LEE J., AHN K., KIM J., KIM Y.M., SUN SIM C., KIM Y. Association between particulate matter concentration and symptoms of atopic dermatitis in children living in an industrial urban area of South Korea. Environmental Reseasrch 160, 462, 2018.

29. DUEÑAS C., FERNÁNDEZ M.C., CAÑETE S., CARRETERO J., LIGER E. Analyses of ozone in urban and rural sites in Málaga (Spain). Chemosphere, 56 (6), 631, 2004

30. COORAY T.M.J.A. Applied Time Series Analysis and Forecasting. Alpha Science, Oxford, USA, 2008.

31. ABDEL-AZIZ A., FREY H.C. Development of hourly probabilistic utility NOx emission inventories using time series techniques: Part I - univariate approach," Atmospheric Environment, 37, 5379, 2003.

32. AGUNG I. G. N. Panel Data Analysis Using EViews. $1^{\text {st }}$ ed.; John Wiley \& Sons (Asia) Pte Ltd, Singapore, 2014.

33. CHATFIELD C. Time series forecasting. $1^{\text {st }}$ ed.; Chapman \& Hall/CRC., United States, America, 2000.

34. BOX G.E.P., JENKINS G.M., REINSEL G.C., LJUNG G.G. Time Series Analysis: Forecasting and Control. $5^{\text {th }}$ Ed.; John Wiley \& Sons, Inc., Hobokens, New Jersey, USA, 2016.

35. RAHMAH M.R., KASHEM M.A. Carbon emissions, energy consumption and industrial growth in Bangladesh : Empirical evidence from ARDL cointegration and Granger causality analysis. Energy Policy, 110, 600, 2017.

36. JUNNINEN H., NISKA H., TUPPURAINEN K., RUUSKANEN J., KOLEHMAINEN M. Methods for imputation of missing values in air quality data sets. Atmospheric Environment, 38 (18), 2895, 2004.

37. SHCHERBAKOV M.V., BREBELS A., SHCHERBAKOVA N.L., TYUKOV A.P., JANOVSKY T.A., KAMAEV V.A. A survey of forecast error measures. World Applied Sciences Journal, 24 (24), 171, 2013.

38. CHAI T., DRAXLER R.R. Root mean square error (RMSE) or mean absolute error (MAE)? Arguments against avoiding RMSE in the literature. Geoscientific model development, 7, 1247, 2014.

39. WANG J., YANG Y., ZHANG Y., NIU T., JIANG X., WANG Y., CHE H. Influence of meteorological conditions on explosive increase in $\mathrm{O}_{3}$ concentration in troposphere. Science of Total Environment, 652 (46), 1228, 2019.

40. WEI W.W.S. Time Series Analysis: Univariate and Multivariate Methods, $2^{\text {nd }}$ ed.; Pearson Addison Wesle: New York, USA, 2006. 